\title{
Studi Tingkat Vandalisme Terhadap Softscape Oleh Pengguna Taman Di Lapangan I Gusti Ngurah Made Agung Denpasar
}

\author{
Angela Sabrina Novianty ${ }^{1}$, Cokorda Gede Alit Semarajaya ${ }^{1 *}$, Ida Ayu Mayun ${ }^{2}$ \\ 1. Program Studi Arsitektur Lansekap, Fakultas Pertanian Universitas Udayana, Jl. P.B. Sudirman \\ Denpasar, 80232, Indonesia. \\ 2. Program Studi Agroekoteknologi, Fakultas Pertanian Universitas Udayana, Jl. P.B. Sudirman Denpasar, \\ 80232, Indonesia \\ *E-mail: coksemarajaya@unud.ac.id
}

\begin{abstract}
Study of vandalism level on softscape by park users at I Gusti Ngurah Made Agung Denpasar. This research was motivated by the existence of vandalism activities in I Gusti Ngurah Made Agung Park Denpasar as the result of human interactions between park user with their environment around this location as a public space. This study aims to identify level of vandalism and user perceptions of vandalism on softscape. The methods used in this research are survey method with collecting data techniques, observation, questionnaire distribution, and literature study. The result of this research showed that there are four variables that caused by vandalism on softscape in this area, such as scratching trees, nailing trees, littering around the plants and picking plants carelessly. The number of vandalism cases on softscape in this area reached about 13 cases that occurred with percentage $0.4 \%$ and western area or part of the field that is on Jalan Udayana is the area that received vandalism the most. Respondents in this study were visitors aged 12- 21 years old, which is the age of vandal on the park. The respondent's perception of vandalism assumed that plants that are close or easy to reach by user and plants that have certain beauty or uniqueness are more vulnerable to be objects of vandalism. The low level of vandalism at I Gusti Ngurah Made Agung is still able to give users a sense of fun.
\end{abstract}

Keywords:city park, softscape, vandalism

\section{Pendahuluan}

Taman adalah sebuah tempat yang sengaja direncanakan oleh manusia, terbentuk di luar ruangan dan untuk menampilkan keindahan dari berbagai tumbuhan dan bentuk alami. Bagi masyarakat perkotaan, khususnya Kota Denpasar ruang terbuka kota sudah menjadi bagian yang sangat melekat dan menjadi tempat masyarakat bertumbuh dan beraktivitas. Selain itu, ruang terbuka dapat menjadi wadah interaksi sosial antar masyarakat perkotaan, sebuah ruang yang sehat dan ruang yang memberikan kesempatan untuk meningkatkan perekonomian. Intensitas kunjungan dan kapasitas taman dalam menampung pengunjung dan karakteristik pengunjung yang berbeda-beda menyebabkan banyak hal dapat terjadi pada taman, salah satunya vandalisme. Vandalisme dapat dikatakan sebagai hasil dari perilaku manusia baik sengaja maupun tidak sengaja karena rendahnya tingkat toleransi manusia akan lingkungan sekitarnya, dengan kata lain perkembangan jaman yang pesat namun kesadaran manusia akan lingkungan semakin menurun. Salah satu Taman Kota yang terdapat di Kota Denpasar, yakni Lapangan I Gusti Ngurah Made Agung Denpasar yang menjadi titik nol Kota Denpasar. Taman yang berukuran 33.810 meter persegi (Dinas Kebersihan dan Pertamanan Kota Denpasar, 2015) tentu menjadi kebutuhan penghuni Kota Denpasar dan masyarakat secara keseluruhan dan telah menjadi suatu kesatuan, ciri khas yang tidak terpisahkan. Pada tempat ini pula banyak hal disuguhkan bagi masyarakat dari semua kalangan, seperti olahraga, rekreasi bersama keluarga, makna historis yang edukatif, dan makna religius yang bisa didapatkan dari Pura Jagatnatha di sisi Timur Taman. Taman ini bersifat publik yang berarti adanya kebebasan kepada siapa saja untuk datang dan menggunakan taman, dengan kata lain, vandalisme bisa saja terjadi di taman ini. Studi ini bertujuan mengidentifikasi tingkat vandalisme yang terjadi pada Lapangan I Gusti Ngurah Made Agung dalam bentuk persentase dan mengetahui persepsi pengguna terhadap vandalisme dan terhadap kenyamanan Lapangan I Gusti Ngurah Made Agung. 


\section{Metode Penelitian \\ 2.1 Tempat dan Waktu Penelitian}

Penelitian ini dilaksanakan di Lapangan I Gusti Ngurah Made Agung yang bertempat di Desa Dauh Puri Kangin, Kecamatan Denpasar Barat, Kota Denpasar Bali. Penelitian ini dilaksanakan dari bulan November 2019 sampai bulan Januari 2020. Pengambilan data dilakukan selama empat belas hari dan tidak terikat pada jam-jam tertentu.

\subsection{Metode Penelitian}

Metode yang digunakan dalam penelitian ini adalah metode survei dengan teknik pengumpulan data, teknik observasi, penyebaran kuesioner, dan studi pustaka.

\subsubsection{Teknik Observasi}

Teknik observasi merupakan penentuan landasan penelitian dan untuk mengumpulkan data yang ada di lapangan. Terdapat dua tahapan dalam melakukan observasi yakni (1) Pra-observasi bertujuan menentukan landasan utama penelitian yang mencakup penetapan tujuan penelitian, penyusunan rencana kerja, penentuan lokasi penelitian dan pengumpulan informasi yang diperlukan untuk memulai penelitian, (2) Observasi merupakan pengumpulan data dengan mengamati kegiatan-kegiatan dan mendokumentasikan hal-hal yang dianggap perlu untuk menunjang penelitian ini yang ada di lapangan.

\subsubsection{Kuesioner}

Penyebaran kuesioner dilakukan dengan tujuan untuk mengetahui faktor lingkungan yang mendorong para pengunjung untuk melakukan tindakan vandalisme pada tapak. Pertanyaan dalam Kuesioner dibuat secara terstruktur untuk memperoleh data mengenai latar belakang pengunjung (umur, jenis kelamin dan pendidikan terakhir) dan faktor lingkungan yang mempengaruhi.

Ditinjau dari subjek penelitian, maka penelitian ini merupakan penelitian populasi masyarakat Kota Denpasar sebagai pengguna Taman Kota Puputan Badung. Menurut Sugiyono (2017) teknik pengambilan data non-probability sampling purposive sampling dengan artian tidak memberikan peluang yang sama pada setiap anggota populasi untuk dipilih menjadi sampel dan adanya pertimbangan dalam pengambilan sampel, seperti adanya batasan umur yang dapat mengisi kuisioner. Batasan usia remaja antara 12 hingga 21 tahun, yang terbagi dalam tiga fase, yaitu remaja awal (usia 12 hingga 15 tahun), remaja tengah/madya (usia 15 hingga 18 tahun) dan remaja akhir (usia 18 hingga 21 tahun). Remaja berasal dari kata adolensence yang berarti tumbuh menjadi dewasa yang mencakup kematangan mental, emosional sosial dan fisik (Hurlock, 2003).

Penyebaran kuesioner dilakukan di empat bagian yang telah ditetapkan sebagai tempat penelitian, yaitu area Utara, area Selatan, area Barat, dan area Timur pada Taman Kota Puputan Badung. Jumlah kuisioner yang tersebar sebanyak 120 kuisioner dimana setiap zona dibagikan sebanyak 30 kuesioner. Penyebaran kuesioner akan berlangsung dari pukul 9 pagi hingga 12 siang dan dilanjutkan dari pukul 3 sore hingga 6 sore. Kuesioner disebar dalam waktu dua minggu untuk mendapat hasil yang maksimal.

\subsection{Analisis Data}

Dalam mengolah data inventarisasi tanaman dan data kuesioner yang didapatkan menggunakan perhitungan jumlah persentase vandalisme pada softscape dan skala likert.

\subsubsection{Penghitungan Jumlah Persentase Vandalisme}

Menurut Pararinarno (2015) perlu adanya penghitungan tindakan vandalisme yang terjad pada tumbuhan proses dalam penghitungan persentase jumlah persentase vandalisme yang terjadi pada lokasi penelitian menggunakan rumus, yaitu:

Persentase individu tumbuhan yang terkena vandalisme

Persentase vandalisme $=\frac{\text { Jumlah individu yang terkena vandal }}{\text { jumlah keseluruhan individu }} \times 100 \%$

Variabel frekuensi bentuk vandalisme pada tumbuhan

$F=\frac{\text { Jumlah ditemukannya suatu bentuk vandal jenis ke-i }}{\text { Jumlah seluruh bentuk vandal pada individu }} \times 100 \%$ 
Rata-rata vandalisme pada tiap individu Rata-rata $=\frac{\text { Jumlah vandalisme }}{\text { Jumlah keselunuhan vandalisme }}$

\subsubsection{Skala Likert}

Penilaian skala likert, dimana menurut Sugiyono (2010:134), skala likert digunakan untuk mengukur sikap, pendapat, dan persepsi seseorang atau sekelompok orang tentang fenomena sosial. Dengan modifikasi skala likert STB: Sangat Tidak Baik (1), TB: Tidak Baik (2), N: Netral (3), B: Baik (4) dan SB: Sangat Baik (5)

\subsection{Batasan Penelitian}

Ruang lingkup yang menjadi Batasan penelitian ini adalah 1. Aktivitas vandalisme yang diamati adalah menggambar atau menulis pada pohon dan mematahkan atau mengambil bagian dari tumbuhan, 2. Responden yang dapat mengisi kuesioner adalah orang yang didapati sedang melakukan tindakan vandalisme dalam pengamatan dengan Batasan usia 12 tahun hingga umur 21 tahun dan dapat menulis serta membaca, 3. Menghitung persentase vandalisme yang terjadi di tiap individu tumbuhan sehingga dapat diketahui tingkat vandalisme yang terjadi pada lokasi penelitian.

\section{Hasil dan Pembahasan}

\subsection{Gambaran Umum Lapangan Puputan Badung I Gusti Ngurah Made Agung}

Lapangan Puputan Badung berada di jantung Kota Denpasar yang lokasinya bersebelahan dengan Museum Bali dan Pura Agung Jaganatha. Di tempat ini merupakan titik nol Kota Denpasar. Adapun batasan yang ada pada Lapangan Puputan sebagai berikut, batas Utara: Jalan Surapati, batas Selatan: Jalan Sugianyar, batas Barat: Jalan Udayana, batas Timur: Jalan Mayor Wisnu. Gambaran Lapangan I Gusti Ngurah Made Agung dapat dilihat pada Gambar 1.

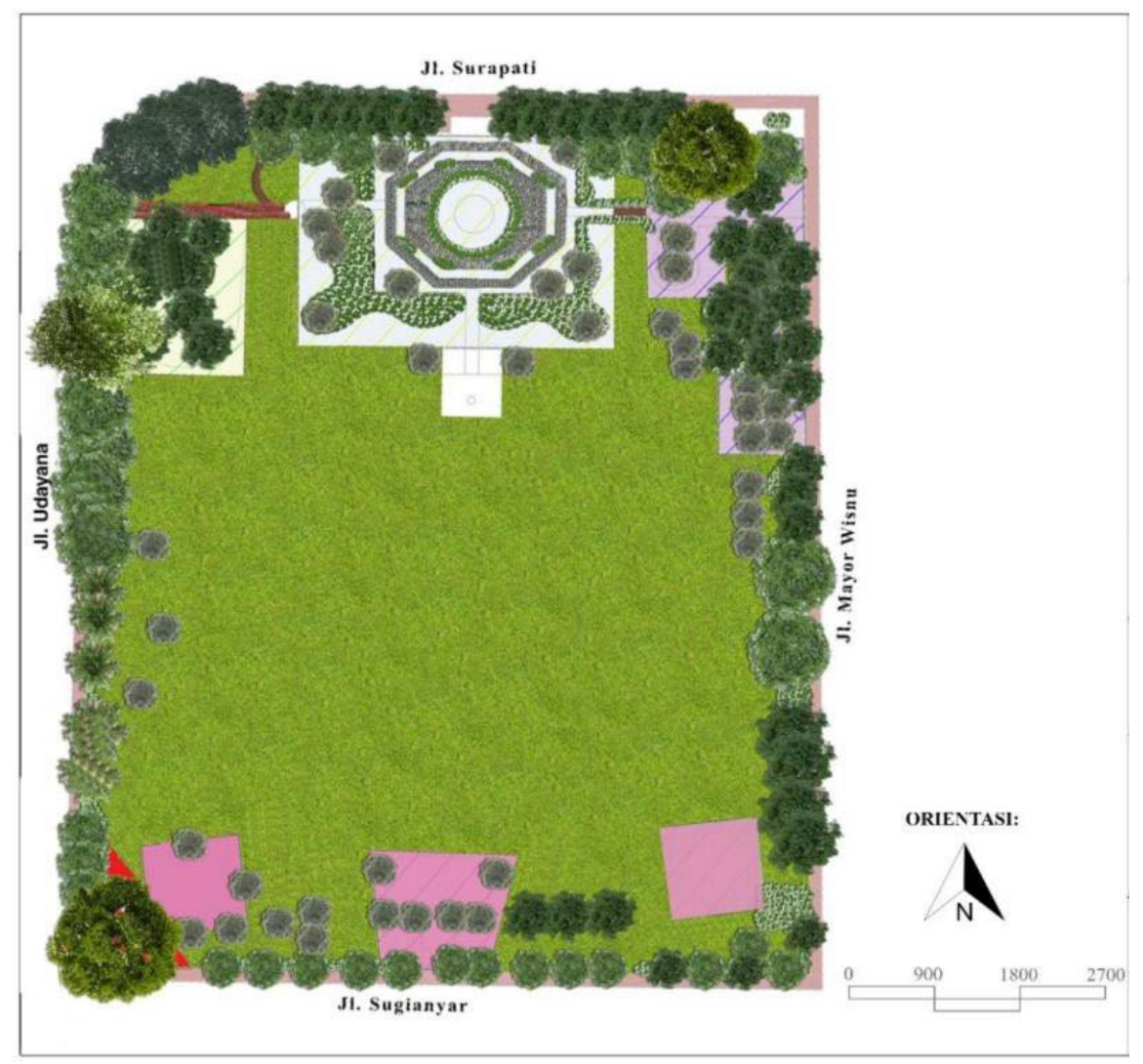

Gambar 1. Lapangan I Gusti Ngurah Made Agung 


\subsection{Inventarisasi Vegetasi}

Tahapan inventarisasi dilakukan dengan melihat kondisi eksisting tanaman dilihat untuk memperoleh informasi yang berkaitan dengan kondisi tapak untuk penanaman vegetasi.

Vegetasi merupakan salah satu elemen pembentuk lanskap. Lapangan Puputan Badung I Gusti Ngurah Made Agung untuk memenuhi fungsinya sebagai RTH publik. Vegetasi ada pada tapak meliputi penutup tanah, semak, dan pohon. Beberapa vegetasi tersebut diantaranya Bungur (Lagerstroemia speciosa), Beringin (Ficus benjamina), Teh-tehan (Acalypha siamensis), dan Rumput Paetan (Axonopus compressus). Vegetasi yang banyak ditemui di taman berupa tumbuhan perdu, semak belukar, beberapa tumbuhan bambu dan tumbuhan perkebunan yang memang merupakan jenis tumbuhan daerah iklim tropis (Nareswari, 2019).

\subsection{Vandalisme yang terjadi pada Lapangan I Gusti Ngurah Made Agung}

Vandalisme yang terjadi pada tapak lapangan paling banyak ditemukan berupa coretan dan goresan pada pohon-pohon peneduh berukutan tinggi $15 \mathrm{~m}$ - 20m yang berada di jalur jogging, membuang sampah sembarangan pada teh-tehan (Acalypha siamensis), dan merusak tanaman dalam bentuk memetik pada

\subsubsection{Persentase Individu Pohon yang Terkena Vandalisme}

Berdasarkan hasil observasi dan inventarisasi yang dilakukan selama dua minggu yang terdiri dari121 individu pohon yang salah satunya adalah bungur (Lagerstroemia floribunda) adalah vegetasi memiliki jumlah terbanyak yaitu 35 individu. Persentase individu pohon yang terkena vandalisme pada Lapangan I Gusti Ngurah Made Agung sebesar 7.43\% dengan jumlah individu yang terkena vandalisme 9 individu. Vandalisme yang terjadi pada pohon dapat dilhat pada Gambar 2, Gambar 3, dan Gambar 4
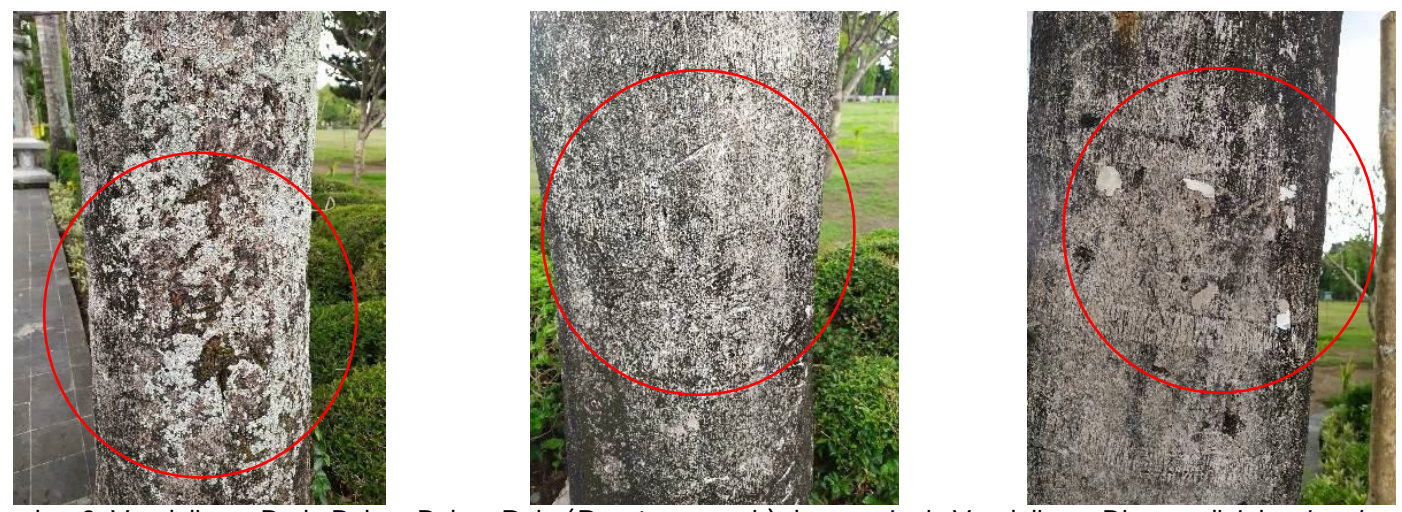

. Gambar 2. Vandalisme Pada Pohon Palem Raja (Roystonea regia) dengan Jenis Vandalisme Digores di Jalur Jogging.
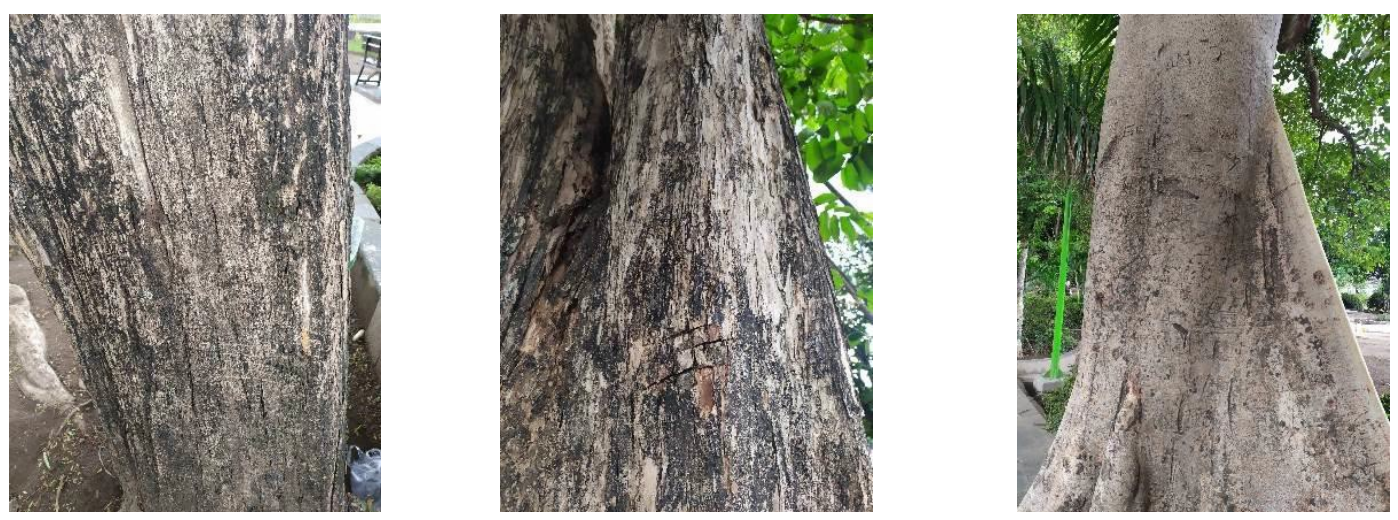

Gambar 3. Vandalisme Goresan Pohon Bungur (Lagerstroemia floribunda) dan Angsana (Pterocarpus indicus) Jalur Jogging. 

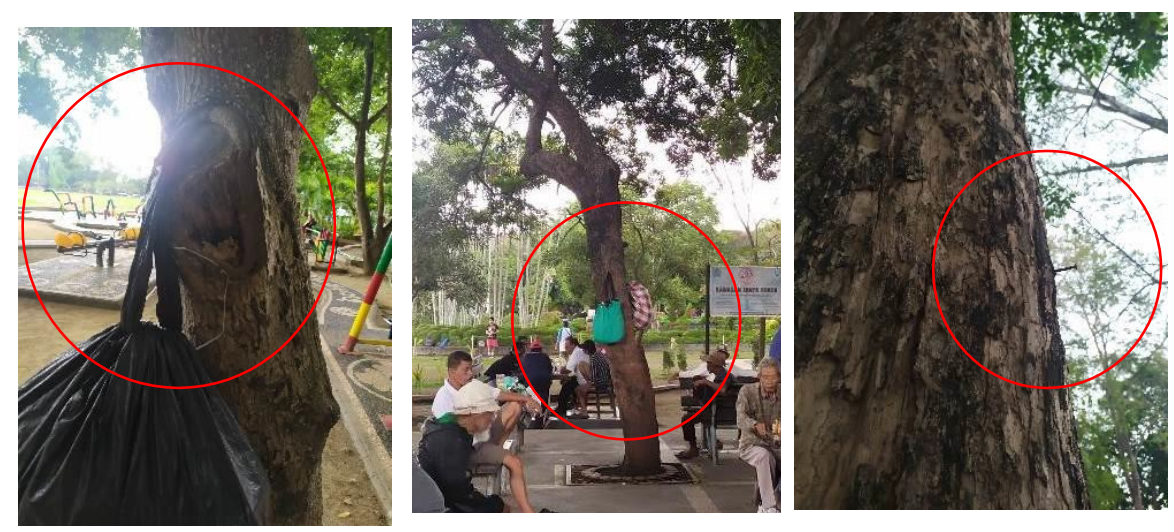

Gambar 4. Vandalisme Memaku Pada Pohon Angsana (Pterocarpus indicus) di Area Playground dan Area Catur

\subsubsection{Variabel Frekuensi Bentuk Vandalisme pada Tumbuhan}

Dalam tindakan vandalisme yang terjadi pada Lapangan I Gusti Ngurah Made Agung terdapat empat jenis variabel vandalisme, yaitu menggores, memaku, membuang sampah pada tumbuhan, dan memetik tumbuhan dengan sembarangan. Sedangkan, jumlah seluruh bentuk vandalisme pada tumbuhan, yaitu 13 kejadian vandalisme yang ditemukan selama observasi dua minggu. Tindakan vandalisme seperti menggores terdapat 6 kejadian dengan tingkat goresan terbanyak diperoleh Pohon Angsana (Pterocarpus indicus) yang berlokasi pada jalur jogging. Persentase yang didapatkan akan vandalisme goresan, yaitu 46.1\%. Dengan tindakan vandalisme seperti memaku pada pohon terdapat 3 kejadian dengan tingkat memaku terbanyak pada satu individu diperoleh Pohon Angsana (Pterocarpus indicus) yang berlokasi pada area catur. Persentase yang didapatkan akan vandalisme memaku, yaitu 23\%. Sedangkan, untuk tindakan vandalisme membuang sampah pada tumbuhan ditemukan sebanyak 2 kali kejadian yang terjadi pada tumbuhan teh-tehan (Acalypha siamensis). Didapatkan persentase sebesar 15.3\%. Demikian pula dengan tumbuhan Andong (Cordyline fruticose) ditemukan tindakanvandalisme memetik sebanyak 2 kali kejadian dan mendpatkan persentase sebesar 15.3\%. Pada Gambar 5 dan Gambar 6 dapat dilihat vandalisme yang terjadi pada tumbuhan dalam bentuk memetik tumbuhan dan membuang sampah pada tumbuhan.
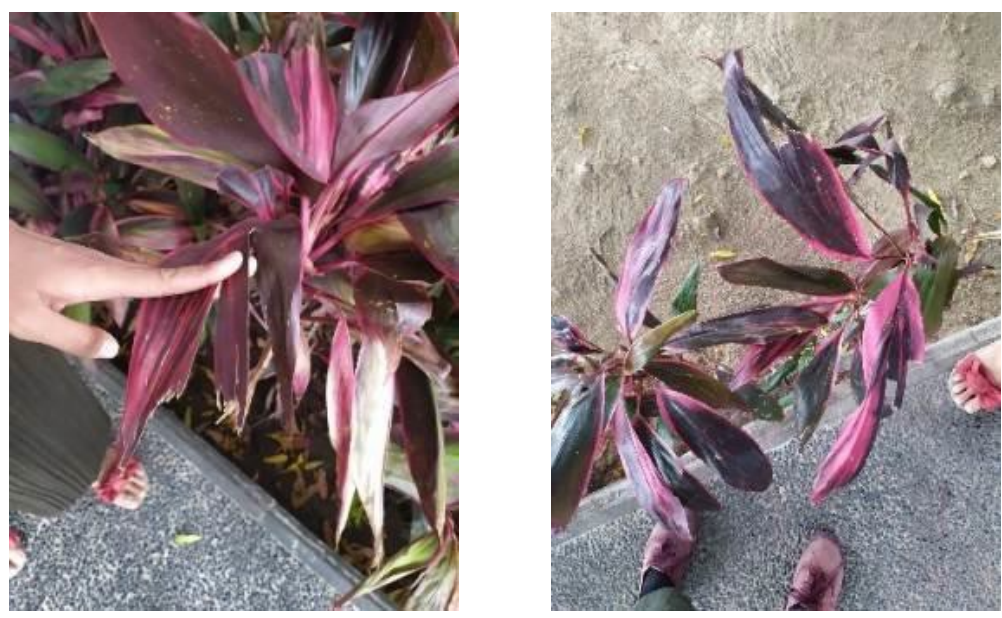

Gambar 5. Tindakan Vandalisme Memetik Tumbuhan Andong (Cordyline fruticose). 

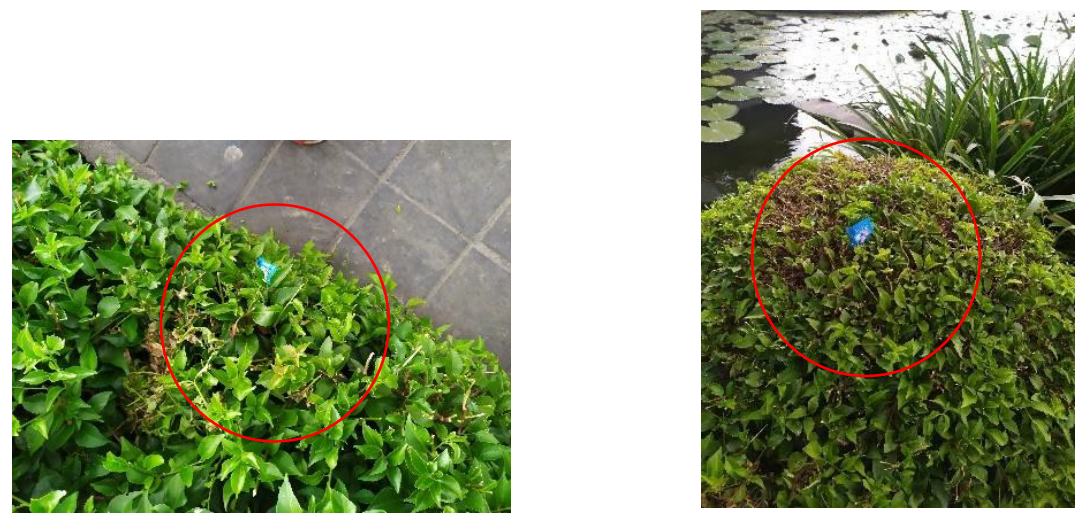

Gambar 6. Tindakan Vandalisme Membuang Sampah pada Tumbuhan Teh-Tehan (Acalypha siamensis)

\subsubsection{Rata-rata Vandalisme pada Tiap Individu}

Rata-rata vandalisme yang didapatkan pada lokasi Lapangan I Gusti Ngurah Made Agung didapatkan dengan nilai sebesar 0.04 untuk tindakan vandalisme menggores pada individu pohon. Nilai rata- rata yang didapatkan dalam tindakan vandalisme memaku pada individu pohon mendapat nilai sebesar 0.02 . Dalam nilai ratarata yang didapatkan tindakan vandalisme memetik pada tumbuhan mendapat nilai sebesar 0.01 , dan nilai rata-rata yang didapatkan bagi tindakan vandalisme membuang sampah pada tumbuhan sebesar 0.01. Pada Tabel 1 dapat dilihat softscape yang terkena vandalisme.

Tabel 1 Softscape yang Terkena Vandalisme

\begin{tabular}{lclc}
\hline \multicolumn{1}{l}{ Nama llmiah } & Jumlah Individu & Jenis Vandalisme & $\begin{array}{c}\text { Jumlah terkena } \\
\text { vandalisme }\end{array}$ \\
\hline Pterocarpus indicus & 27 & Memaku Menggores & 3 \\
Lagerstroemiafloribunda & 27 & Menggores & 1 \\
Roystonea regia & 35 & Menggores & 2 \\
Acalypha siamensis & 11 & Membuang sampah & 2 \\
Cordyline fruticose & - & Memetik tumbuhan & 2 \\
\hline
\end{tabular}

\subsection{Pemetaan vandalisme pada softscape}

1. Bagian Utara

Bagian Utara merupakan bagian dari Jalan Surapati dan merupakan area yang digunakan oleh pengunjung untuk melakukan aktivitas bermain sepatu roda dan skate board. Pada area ini vandalisme yang ditemukan, yaitu membuang sampah sembarangan pada tanaman teh-tehan (Acalypha siamensis), tanaman ini berada pada monument Puputan Badung.

2. Bagian Selatan

Aktivitas yang terjadi pada Bagian Selatan atau Jalan Sugianyar hanya terfokus pada kegiatan olahraga dan kegiatan pengembangan diri, seperti menari. Fasilitas dan ruang yang ada digunakan secara maksimal oleh pengunjung, menjaga kebersihan, dan kelestarian tanaman yang ada. 


\section{Bagian Timur}

Pada bagian Timur atau Jalan Mayor Wisnu adalah area yang dikunjungi pengunjung untuk bermain catur dan area membeli makanan yang dijual dan di area ini didominasi oleh orang tua. Vandalisme yang ditemukan pada aea ini adalah pohon yang dipaku dan dijadikan tempat menaruh barang bagi pengunjung.

\section{Bagian Barat}

Bagian Barat marupakan bagian dari Jalan Udayana dan area yang ramai dilalui oleh pengguna karena memiliki jalur jogging, playground, dan area olahraga. Area ini terkena vandalisme terbanyak dari hasil banyak kegiatan yang tertumpu pada Bagian Barat. Vandalisme yang terlihat pada area ini adalah coretan dan goresan pada pohon peneduh jalur jogging dan pohon yang dipaku pada playground.

\subsection{Persepsi Pengunjung}

Vandalisme bukanlah fenomena modern dan dengan mengabaikannya begitu saja tidak akan mengurangi efek yang dirasakan bagi pengunjung tapak.

Vandalisme yang terjadi pada Lapangan I Gusti Ngurah Made Agung karena adanya keterkaitan dengan persepsi pengunjung terhadap tumbuhan yang berada dekat dengan jangkauan pengguna dan persepsi pengunjung terhadap tumbuhan yang memiliki keindahan atau keunikan terentu.

1. Persepsi pengunjung terhadap tumbuhan yang berada dekat dengan jangkauan pengguna

Dari penyebaran kuesioner yang telah dilakukan dapat diketahui apa yang menjadi pandangan pengguna terhadap Lapangan I Gusti Ngurah Made Agung yang merupakan tapak yang banyak sekali dikunjungi dari berbagai kalangan dan digunakan berbagai macam kegiatan.

Dalam hasil penyebaran kuesioner menunjukkan bahwa pengunjung mengetahui bahwa tindakan vandalisme akan dipengaruhi dari jarak pelaku vandalisme dengan vegetasi. Persentase persepsi pengunjung akan tindakan vandalisme yang terjadi pada tumbuhan yang berada dekat dengan jangkauan pengguna taman dapat dilihat pada Gambar 7.

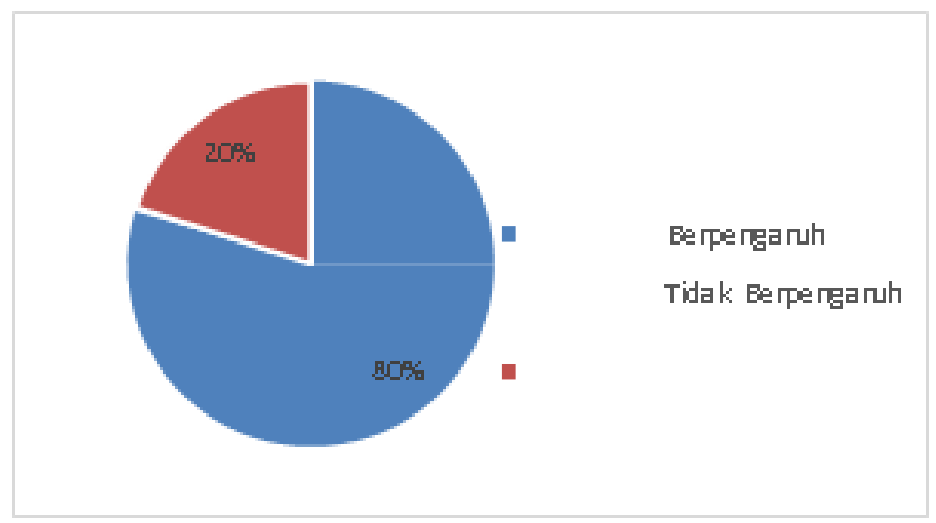

Gambar 7. Persepsi Pengunjung akan Tindakan Vandalisme pada Tumbuhan Berada Dekat Jangkauan Pengguna

2. Persepsi pengunjung terhadap tumbuhan yang memiliki keindahan atau keunikan terentu

Para pengunjung yang menjadi responden dari kuesioner yang telah disebar setuju dengan pernyataan bahwa faktor yang menunjang seseorang untuk mematahkan atau merusak tumbuhan di Lapangan I Gusti Ngurah Made Agung karena faktor keindahan atau keunikan yang dimiliki suatu jenis vegetasi, dengan demikian dapat menambah rasa ingin tahu dan keinginan bagi pelaku vandalisme dalam melakukakan tindakan vandal tersebut yang bisa saja timbul tanpa disadari pengunjung. Persentase yang ditunjukkan dalam Gambar 8 menyatakan tindakan vandalisme yang terjadi pada tumbuhan memiliki keindahan atau keunikan tertentu sebesar 85\%. 


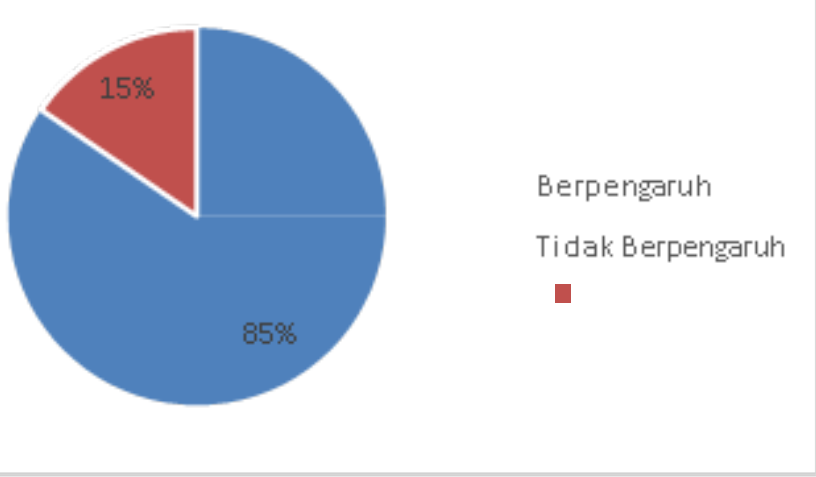

Gambar 8. Persepsi Pengunjung akan Tindakan Vandalisme pada Tumbuhan yang Memiliki Keindahan/ Keunikan

\subsection{Persepsi pengunjung akan kenyamanan Lapangan Puputan Badung I Gusti Ngurah Made Agung}

a. Persepsi kenyamanan pengunjung terhadap Lapangan I Gusti Ngurah Made Agung

Dalam mendapatkan persepsi kenyamanan pengunjung terhadap Lapangan I Gusti Ngurah Made Aggung menggunakan Skala Likert. Dari penilaian yang diberikan responden, persentase yang digambarkan dalam Gambar 9 akan kenyamanan mendapat nilai Baik dari responden sebesar $47 \%$.

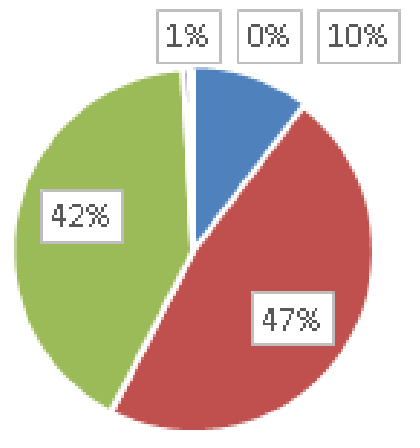

- 5 (Sangat Baik)

- 4 (Baik)

3 (Netral)

2 (Tidak Baik)

1 (Sangat Tidak Baik)

Gambar 9. Persepsi Kenyaman Pengunjung Terhadap Lapangan I Gusti Ngurah Made Agung

b. Persepsi pengunjung terhadap pengelolaan kawasan dan pengelolaan pengunjung

Dalam penilaian persepsi pengunjung akan pengelolaan kawasan dan pengelolaan pengunjung yang mengacu pada Gambar 10 sebanyak 36\% responden menilai sangat baik yang sudah dilakukan oleh pengelolaan Lapangan I Gusti Ngurah Made Agung.

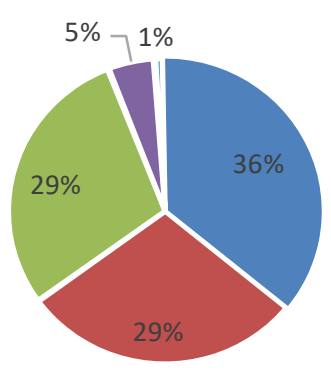
- 5 (Sangat Baik)
- 4 (Baik)
- 3 (Netral)
- 2 (Tidak Baik)
- 1 (Sangat Tidak Baik)

Gambar 10. Persepsi Pengunjung Terhadap Pengelolaan Kawasan dan Pengelolaan Pengunjung 
c. Persepsi pengunjung terhadap sarana dan prasarana Lapangan I Gusti Ngurah Made Agung

Sarana dan prasarana menurut Jayadinata (1992 dalam Juliawan,2015:5) prasarana merupakan suatu faktor potensial yang sangat penting dalam menentukan arah dan masa depan. Bagi pengunjung Lapangan I Gusti Ngurah Made Agung dalam sarana dan prasarana yang diberikan dari tapak lapangan yang mengacu pada Gambar 11 mendapat nilai Netral yaitu sebesar 44\%. Dalam artian bahwa sebanyak 42 responden setuju sarana dan prasarana Lapangan I Gusti Ngurah Made Agung tidak memberikan kesan tertentu pada pengunjung.

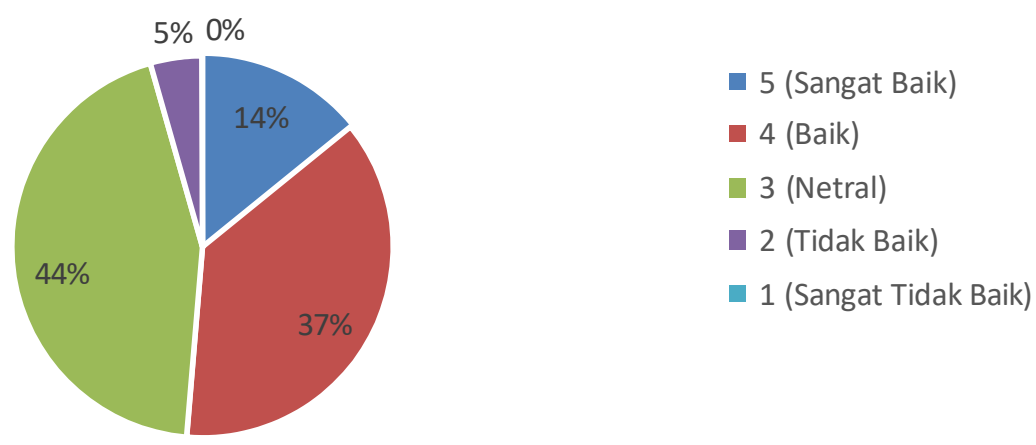

Gambar 11. Persepsi Pengunjung Terhadap Sarana dan Prasarana Lapangan I Gusti Ngurah Made Agung

\section{$4 \quad$ Penutup \\ 4.1 Simpulan}

Berdasarkan pembahasan di atas maka dapat disimpulkan bahwa vandalisme yang terjadi pada Lapangan I Gusti Ngurah Made Agung termasuk dalam tingkatan rendah dengan jumlah 13 individu tanaman yang terkenda vandalisme dengan persentase $0.4 \%$, di mana pada Bagian Barat vandalisme terbanyak terjadi. Dalam persepsi responden akan vandalisme yang terjadi tanaman yang berada dekat dengan jangkauan pengguna taman dan tanaman yang menarik atau memiliki keunikan tertentu menjadi daya tarik pelaku vandalisme pada Lapangan I Gusti Ngurah Made Agung. Dengan cukup tinggi angka berpengaruh akan keunikan atau keindahan yang ada pada vegetasi, maka butuh adanya kerja sama yang baik dari pihak pengelolaan Lapangan I Gusti Ngurah Made Agung dengan pengunjung dapat diharapkan adanya rasa memiliki dari pengunjung dan adanya sikap sigap dari pihak pengelolaan sesaat adanya tindakan vandalisme terlihat seperti yang dinyatakan oleh Marvin (1978)

Persepsi akan Lapangan I Gusti Ngurah Made Agung secara umum, bahwa responden merasa nyaman, penilaian terhadap pengelolaan kawasan dan pengelolaan pengunjung sudah sangat baik, dan penilaian akan sarana dan prasarana sudah cukup.

\subsection{Saran}

Hasil dari penelitian ini salah satunya dapat diketahui bahwa Lapangan I Gusti Ngurah Made Agung merupakan RTH publik yang merupakan salah satu ciri Kota Denpasar yang dikelola dalam kategori baik oleh Pemerintah Kota Denpasar dan sepantasnya diberi apresiasi. Pengelolaan yang baik tersebut dapat diketahui dari persentasi vandalisme yang terjadi sangat kecil. Namun demikian, vandalisme yang rendah di Lapangan I Gusti Ngurah Made Agung diperlukan pertimbangan bagi Pemerintah Kota Denpasar tindakan apa yang perlu dilakukan guna menyikapi vandalisme yang terjadi dan penelitian lanjut mengenai penataan vegetasi.

\section{Daftar Pustaka}

Jayadinata, Johara T, \& Juliawan (Ed). 2015. Pembangunan Desa dalam Perencanaan. Bandung: ITB.

Krohn M.D., Massey J.L., Skinner W.F. (1987) A Sociological Theory of Crime and Delinquency. In: Morris E.K., Braukmann C.J. (eds) Behavioral Approaches to Crime and Delinquency. Springer, Boston, MA

Marvin, Black. 1987. Journal of Tree Vandalism: Some Solutions. Vol 57, 114-116.

Mulyana, S. 2013. Kajian jenis pohon potensial untuk hutan kota di Bandung, Jawa Barat. Jurnal Analisis Kebijakan 
Kehutanan. 10(1):58-71. Doi:10.20886/jakk.2013.10.1.58-71.

Nareswari, I Gusti Ayu Tria. 2019. Analisis Kesesuaian Vegetasi di Lapangan Puputan Badung I Gusti Ngurah Made Agung, Denpasar, Bali. Skripsi (tidak dipublikasikan) Universitas Udayana, Fakultas Pertanian, Program Studi Arsitektur Pertanaman.

Pararinarno, Anggih \& Setiawan, Agus \& Master, Jani. 2015. Vandalisme Dalam Kegiatan Wisata Hutan Di Taman Kupu-Kupu Gita Persada Bandar Lampung. Jurnal Sylva Lestari. 3. 1. Doi:10.23960/js/331-10. Hurlock. 2003. Psikologi Perkembangan Suatu Pendekatan Sepanjang Rentang Kehidupan, Erlangga, Jakarta

Sugiyono, 2010. Metode Penelitian Pendidikan Pendekatan Kuantitatif, Kualitatif, dan R\&D. Bandung: Alfabeta, h.3. 95. 